\title{
アクリル酸ブチルーアクリルニトリル共重合体の 濃厚溶液粘度におよぼす諸因子+
}

（昭和35年11月24日 受理）

\section{立 道 秀 麿}

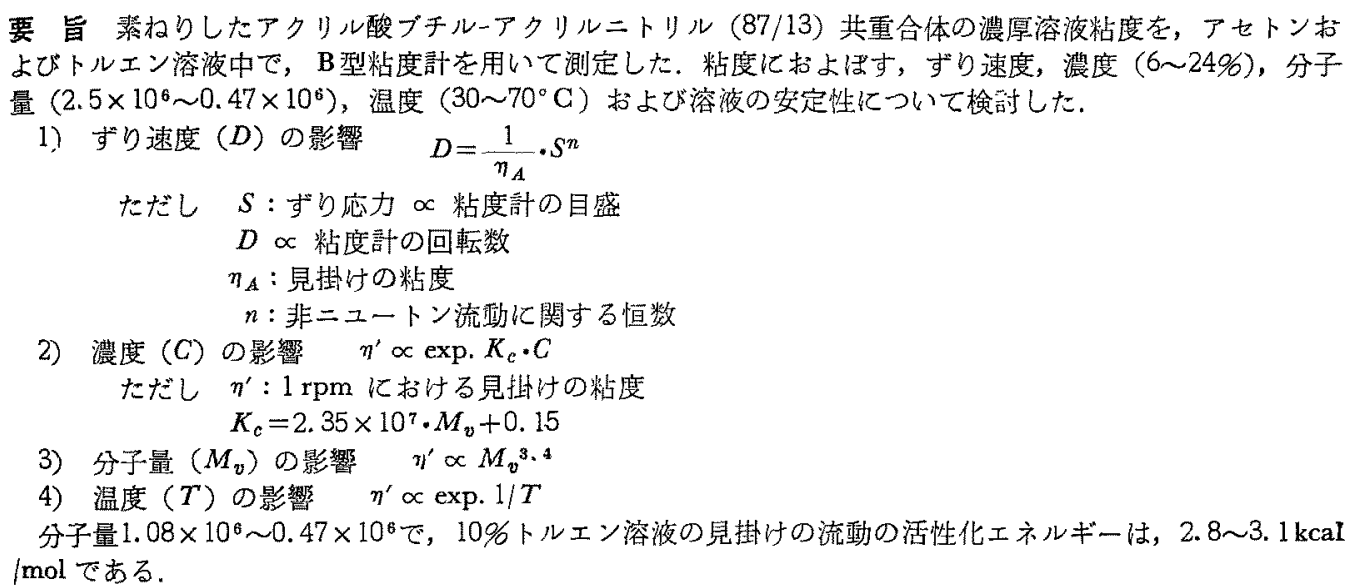

1. 緒匐

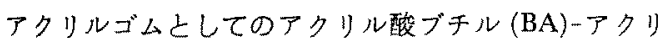
ルニトリル $(\mathrm{AN})(87 / 13)$ 共重合体は，弾性体として応用 される以外にコーデイング村料ししてあ利用されるが， この場合濃厚溶液の阽度或は構造粘性等は, 加工㭙に重 要な因子となり，詳細な知見を必要とする。他の高分子 の濃厚溶液については，三，三の報告があるが》，アク リルゴムについてはまだ明らかでない，アクリルゴムの 未素数り物は，不溶性のゲルを含まないが，重合度は数

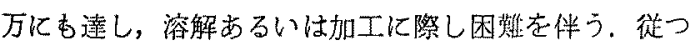

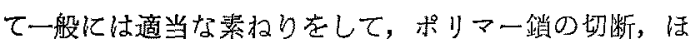
ぐしを行い，溶液粘度，構造粘性を低下させ作業性老向 上させるのが普通である，との郝告では前報で检馀され た希薄溶液の諸因子を更に濃厚溶液にまで拡張し, 特に

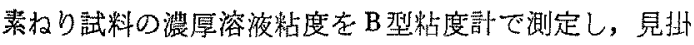
けの阽度，或は構造粘性に战上活す，溶液濃度，分子 量, 温度依存性和上び溶液の安定性等の基整的因子学検 嗼した。

* 名古屋市港区昭和町 17 : 東可合成化学 $\mathrm{K} \mathrm{K}$ 研究所

十 本報を[アクリルゴムに関する研究(第10報)]とす る。【第9 啟 立道, 小林：ゴム協, 34, 402(1961)]

\section{2. 実 験 方 法}

\section{1 共重合体溶液の調整}

BA/AN 共重合体住，前報乙同じ様に乳化重合体を種

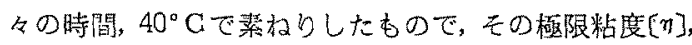
Huggins $の k^{\prime}$ ，分子量俵1に示した通りである，溶液 は常温で約 2 日間かきまぜながら溶解して作製した。ポ リマー㳪度は, 粘度测定の都度決定した。溶媒は主しし てアセトンを用い，高い温度で測定する場合は，蒸発愦 差を考虑してトルエンを使用した。

\section{2 粘度測定方法}

濃厚溶液の粘度は，同心円筒回転型として B M型粘度 計 (東宗計器㱔) を用い，30 $\mathrm{C}$ の恒温槽中にて测定し た。溶液の容器は，内径 $80 \mathrm{~cm}$ の硝子円筒である。測定 䛊差については, 使用書, その他 ${ }^{22}$ 宏考として補正し た。希薄溶液粘库は前郝に準じて測定し，分子暴は炊式 3によよ計算した。

$$
[\eta]=1.70 \times 10^{6} \cdot M_{v}{ }^{0.68}
$$

\section{3. 実験結果および考察}

\section{1 非ニユートン流動性におよぼす諸因子}

高尔子の濃厚溶液は，非二ュートン流動を示古とと加 
表 1 素1 构料の溶液粘度之分子量

\begin{tabular}{|c|c|c|c|c|c|c|c|c|c|}
\hline 試 料 No. & 450 & 451 & 452 & 454 & 456 & 460 & 470 & 490 & 510 \\
\hline 素和り時間 $(\mathrm{min})$ & 0 & 1 & 2 & 4 & 6 & 10 & 20 & 40 & 60 \\
\hline$[\eta](l / g)$ & 0.445 & 0.335 & 0.310 & 0.277 & 0.249 & 0.225 & 0.175 & 0.149 & 0.140 \\
\hline$k^{\prime}$ & 0.42 & 0.43 & 0.37 & 0.34 & 0.36 & 0.40 & 0.36 & 0.34 & 0.36 \\
\hline$M_{v} \cdot 10^{-6}$ & 2.51 & 1.66 & 1.48 & 1.27 & 1.08 & 0.944 & 0.653 & 0.513 & 0.470 \\
\hline
\end{tabular}

多く知られており，叉の流動状態はレオロジー方程式上 り，ずり速度一ずり応力曲線を決定することによつて知 るととができる。一般には，DはSの圂数となり

$$
\begin{aligned}
& D=f(S) \cdots \cdots \\
& \text { ニュートン流動では }
\end{aligned}
$$$$
D=\frac{1}{\eta} S
$$

よなって， クは絶対粘度(ポイズ)としての意味を持つ。

流液の $D$ 或は $S$ 虔めるには，しばしば閣心月筒 回転型粘度計が用いられるが，その中，外筒固定内筒回 転型である Brookfield 型粘度計（B型粘度計）は，工業 的管理用として簡便に使用されている゙，乙の粘度計で は，篅密な $D, S$ の测定は無理であるが，半定量的な研 究の手段としては，恥り用いられている25) 8).

非二ニートン流動の場合，1）式が䕄関数型

$$
D=\frac{1}{\eta_{A}} \cdot S^{n}
$$

（ただし， $\eta_{A}$ は見挂けの蛅度， $n$ は槥造粘性指数） で示される場合が多いが，その時同心円筒型粘度計上り

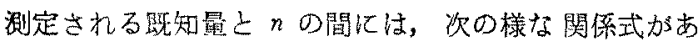
$3^{9}$.

$$
\Omega=\frac{1}{2 n \eta_{A}} \cdot\left(\frac{M}{2 \pi h}\right)^{n} \cdot\left(\frac{1}{R_{i}^{2 n}}-\frac{1}{R_{o}^{2 n}}\right) \cdots \cdots(4)
$$

ここで $M:$ トル， $\Omega$ : 角速度， $R_{i}$ : 内筒の半径, $R_{\mathrm{o}}$ : 外筒の击径, $h:$ 内筒の浸漬している高さ。

別に $D, S$ も比較的簢监な式であらわすととが出来了 が，B型粘度計では，ロータの寸法，末端効果トルク等

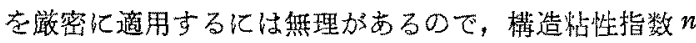
のみを対称とする。

式(4)加ら $\log \Omega$ 之 $\log M$ の関係直楾を求めれば，そ

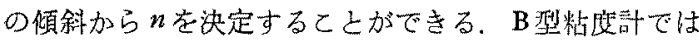
$\Omega ， M$ はそれぞれ炊の様に执き加えられるから，

$$
\begin{aligned}
& \Omega=2 \pi R(R: \text { 回転数 } \mathrm{rpm}) \\
& M=k_{1} m \ldots \ldots \ldots \ldots \ldots \ldots \ldots \ldots \ldots \ldots \ldots \ldots \ldots \ldots
\end{aligned}
$$

( $k_{1}:$ ば放に関する常数， $m:$ 目盛の娈み)

$\log R$ 上 $\log m$ の值線の傾斜加ら $n$ を求兴ことができ る. 二ュートン流動では $n=1$, 韭二ュートン流動では $n \neq 1$ である。したがって種っの系で $n$ 在求めれば, 非
ニュートン流動への寄与の傾向を知ることができる。

素秝りをしたものとしないゴムのアセトン溶液の見掛 けの粘度を程々の回転数で测定し，両者の掭係対数く

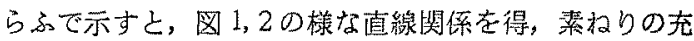
分されたゴムの粘度は，回転数に依存しない二ュートン 流動を示し(図 1)，未菜ねりゴムは，裖度によって回転 数に著しく依存しているととが判る(図 2)，さらに $\log$ $R$ 乙 $\log m$ の関係におき加えてみると，図 3 の様な直線 が得られ，一応籍関数型式(3)が成立し，式(4)に㧍ける構 造粘性指数 $n$ を，図 3 の直線の傾斜から求めることがで きる。

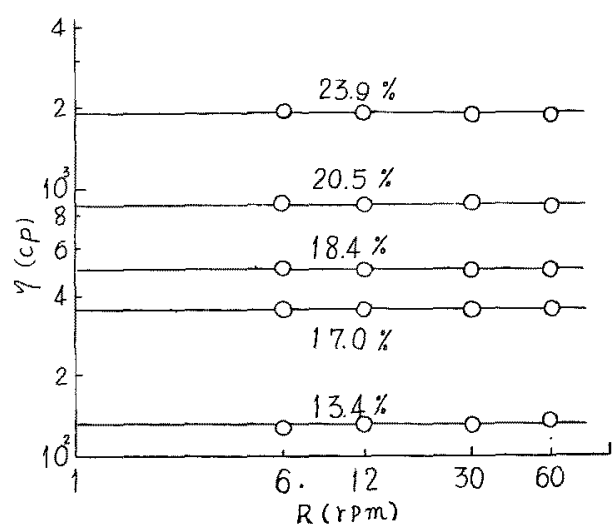

图 1 絜妇り試料の $\log \eta-\log R$ の関係 (No. 510)

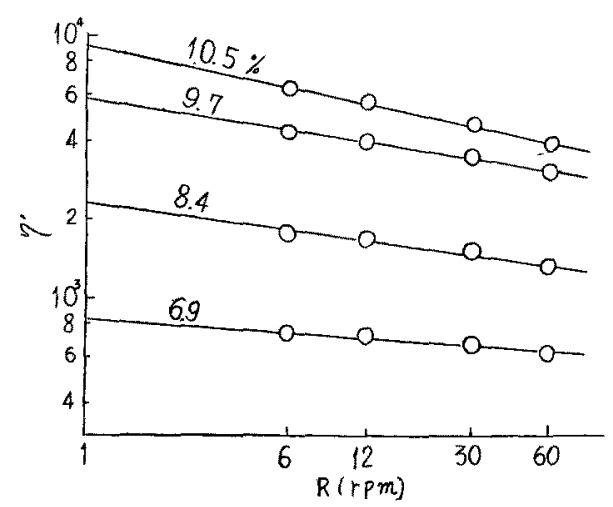

図2末素柏り試料の $\log \eta^{\prime}-\log R$ の関係 (No. 450) 


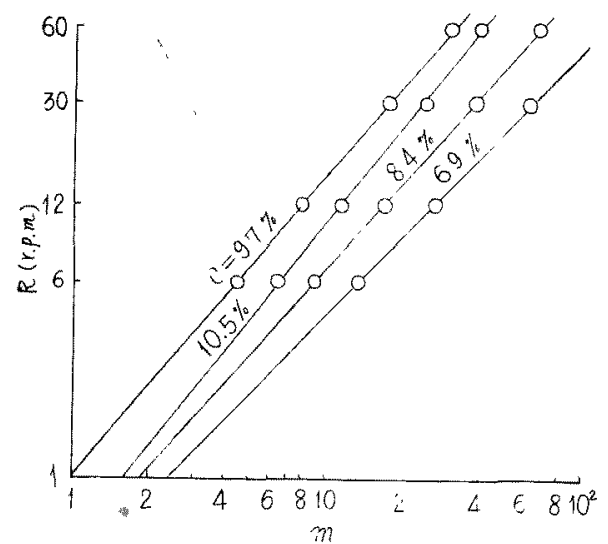

因 3 末菜和り試料の $\log R-\log m$ の成係

との様にして求めた $n$ を，素权り程度の異った試料 について種々の濃度で比較してみると, 図4の様になっ

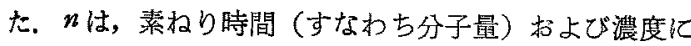
著しく低存し，特に分子量の高い6のは謴度の依存性む 大きい。

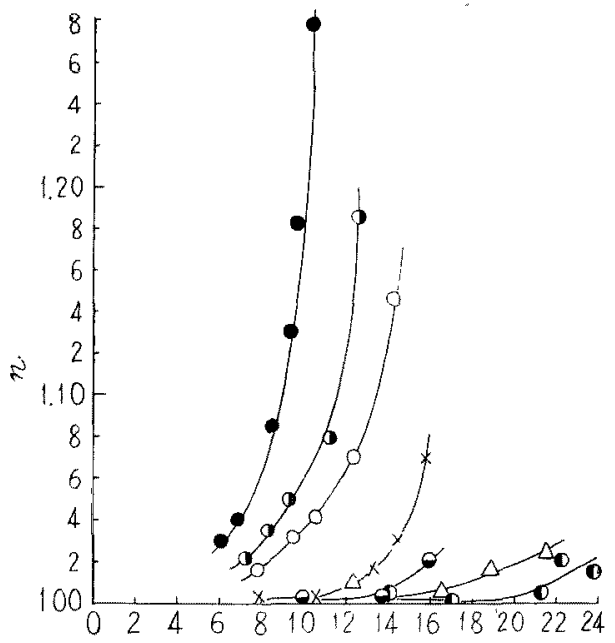

図4nの分子量及ざ滥度低存性 素初り時間 $(\mathrm{min})$

0,01 ,

$\bigcirc 2, \times 4, \odot 6, \triangle 20, \triangle 60$

\section{2 見掛けの粘度の濃度および分子量依存性}

$n>1$ である様な系に执いて B 型怗度汁で求められた 粘度は, 絶対粘度としての意咋奔持大ないが, 図 2 の直

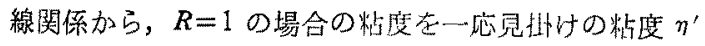
$(R=1)$ として，分子量，䀼度との関係データを整理し てみよう.

柍々の素ねり試料について $\ln \eta^{\prime}(R=1)$ と淡度 $C$ 上の (129)
関係を求めると，図 5 の様な直線関係を得大。图加ら明 らかな様に 6) 式が成立する。

$$
\eta^{\prime}=\eta^{\prime}{ }_{Q} \cdot e^{K_{c} C \ldots}
$$

$\eta^{\prime}{ }_{0} ， K_{c}$ はいずれも分子量の函数である， $K_{c}$ と分子 睹は, 図6 加次式の様な 分子量に関する一次式之な 万.

$$
K_{c}=2.35 \times 10^{-7} \cdot M_{v}+0.15
$$

柿り塩化ビニールのテトラヒドロフラン濃厚溶液系て

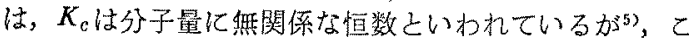

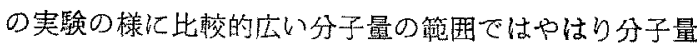
に依存する。

一方図 5 のデーターについて $\log \eta^{\prime}(R=1) \& \log M_{v}$ 之の関係を求める之，图 7 の㥞な直線関係が得られ，次 式在得る。

$$
\eta^{\prime}=K_{M} \cdot M_{v}^{3.4}
$$

$K_{M}$ は濃度の函数である，上式は溶融粘度および濃厚 溶液のある限界分子量以上の高分子量で認めら机ている 式之同形で, 指数 3.4 は, ポリスチレン10), ポリメタア クリル酸メチル11，㪶リビニールアルコール多等につ いて得ら机ている値上一致する。限界分子量以下儿なる

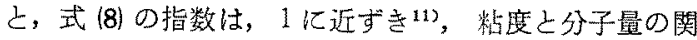
係直線は二つの直線であらわされ，㖤折点(限界分子量) が認めら机ているが，ての実験では全体として高分子 量, 高渻度側になっているためか屈折点が認められず一 本の直線として示された，指数 3.4 を示吉棁な領域では

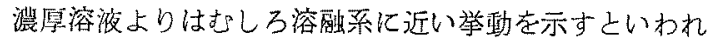
ている11)

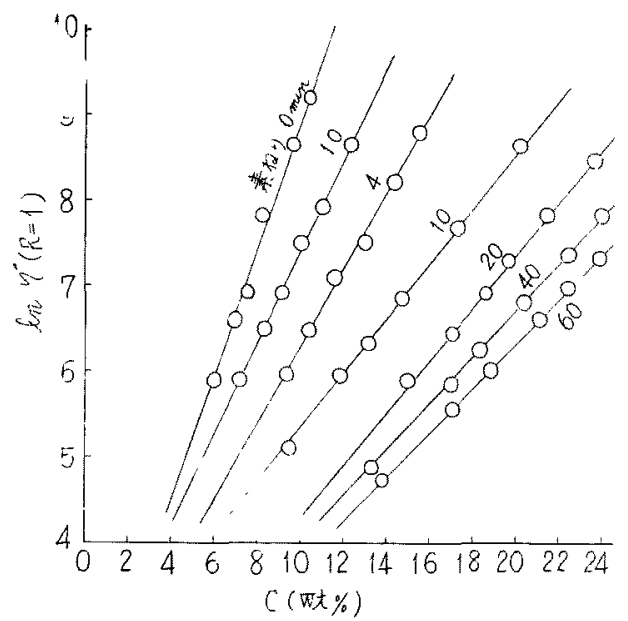

图 $5 \ln \eta^{\prime} \leq C$ の関係 


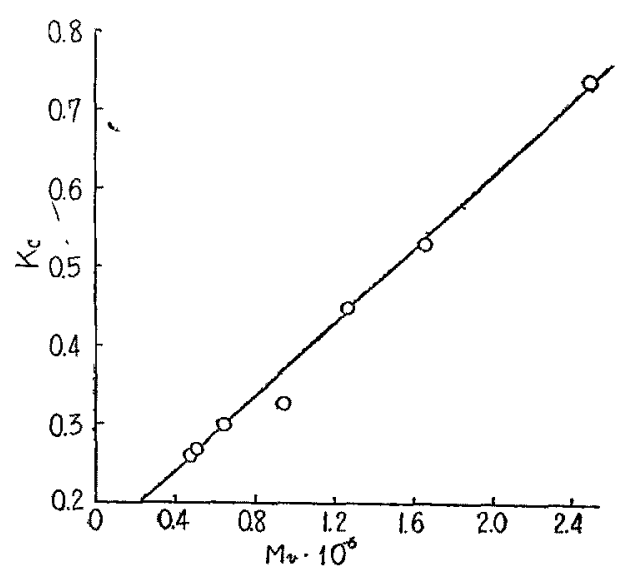

図6 $K_{c}$ と分子量の関係

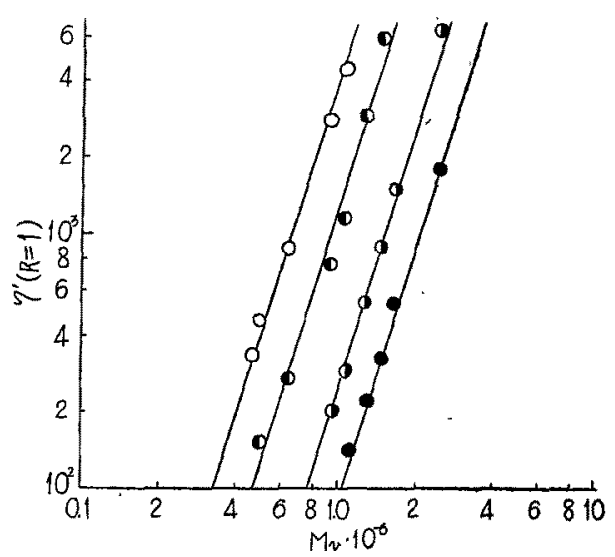

図 $7 \log \eta^{\prime}$ ¿ $\log M_{v}$ の関係

濃度 $\bigcirc 18 \%, \bigcirc 14 \% ， \bigcirc 10 \%$ 8\%

\section{3 未素ねり試料の濃厚溶夜の安定性}

高分子の罘厚溶没は，ポリアクリルニトリルク，ポリ 塩化ビニール5), ポりビニールアルコール12)で䜑められ ている様に，しばしば放置中に，粘度あるいは構造粘性 が著しく変化し，ゲル化するととが報告されている。と の実験の粘度は，常温で溶解後 $1 \sim 2$ 日後に测定したす のであるが，さらに長期間放犆した時の影響について検

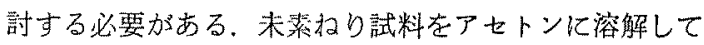
約 1 ケ月間， $30^{\circ} \mathrm{G}$ で放置し，その間に測定した見掛け の粘度 $\eta^{\prime}(R=1)$ 老濃度に対して整理し, 图 8 の様な結 果老得た。

$\ln \eta^{\prime}$ とCの関係は，試㩽が一定である限り，放置期 間にかかわらず，ほほーつの直線で表わされる，したが って BA/AN 共重合体の溶液は，3〜9\%程度の濃度で は，他の有極性高分子に較べて安定である.

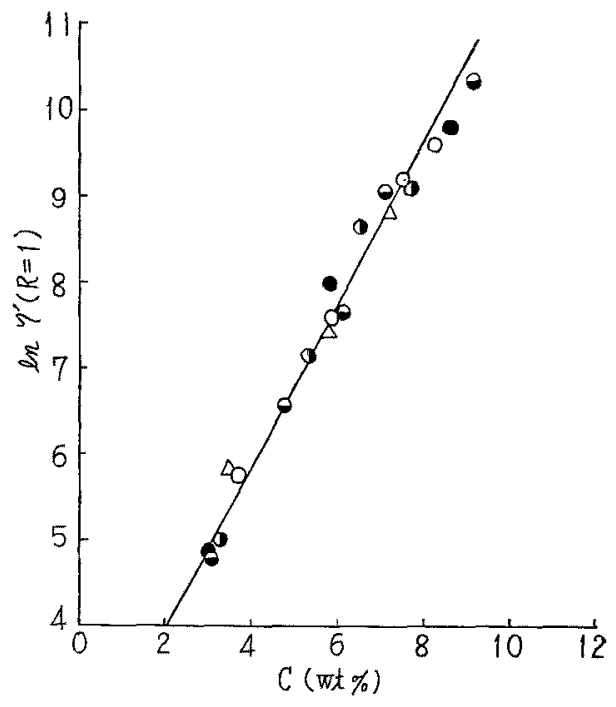

国 8 嚓湤粘度の安定性 $\left(30^{\circ} \mathrm{C}\right.$, アセトン $)$

$$
\text { ○日, } 0 \text { 日打, }
$$
$\triangle 21$ 日, $\bigcirc 28$ 日

\section{4 粘度の温度依存性}

濃厚溶㳸の粘度に方よぼす测定温度の影響をトルエン 溶液（10，䇺度）について検討した，或る程度素教りを した共重合体について，粘度と $1 / T$ の関係は図9の様 な直線さなり，ての直線の傾斜加ら見掛けの流動の活性 化エネルギーを算出すると表 20 棁になる。

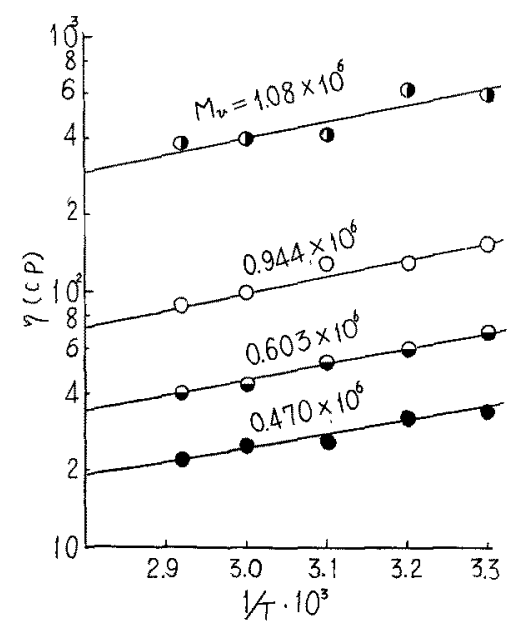

図9 $\log \eta\llcorner 1 / T$ の関係(10，，トルエン)

表 2 流斬の活性化エネルギー上分子量の閣係

\begin{tabular}{lllll}
\hline$M_{v} \cdot 10^{-6}$ & 1.08 & 0.944 & 0.603 & 0.470 \\
$E(\mathrm{Kcal} / \mathrm{mol})$ & 3.10 & 3.04 & 2.85 & 2.77 \\
\hline
\end{tabular}


これらの溶液粘度は，回転数によってほとんど変らず

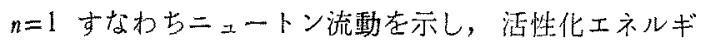

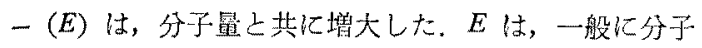
量, 濃度の增吅するにつれて大きくなるが，ポリアクリ ルニトリルーヂメチルホルムアミド采の同程度の淡度上 此較すると ${ }^{677)}, \mathrm{BA} / \mathrm{AN}$ 共霍合体は，非極性のブチルエ ステルを多く含扎た分子量が大きいにもかかわらず低 い活性化エネルギーを走した。

終りに発表至訢而された会社当局ならびに大㛢研究所 長に樑䝰いたします。

文献

1) 占部，ゴム協：28，393 (1955)
2) 旒井，跲木：高分子化学，13，1 (1956)

3) 立道，小林：ゴム協，34，402(1961)

4) R.L. Bowles, R.P. Davie, W.D. Todd : Modern Plastics 33, No.3, 140 (1955)

5) 吉阔 : 工化, 59, 936 (1956)

6) 片山，坂場：高分子化学，13，152 (1956)

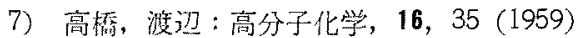

8) 内蕂, 浮田, 小南：高分子化学，14，117 (1957)

9）中川，神戸：“レオロジー”p. 324 (1959) みすず 霄蒋

10) T.G. Fox, P.T. Flory : J. Appl. Phys., 21, 581 (1950)

11) F. Bueche $\cdot$ J.Appl. Phys, 26, 738 (1955)

12) 前田, 河含, 柏木：高分子化学，13，193(1956)

\section{STUDIES OF ACRYLIC RUBBERS ( $X$ ) FACTORS ON VISCOSITY OF CONCENTRATED SOLUTION OF BUTYLACRYLATE-ACRYLONITRILE COPOLYMER}

Hidemaro Tatemichi (Research Department, Tõa Gōsei Chemical Industry Co., Ltd. Shôwa-cho, Minatoku, Nagoya-shi, Aichi-ken, Japan)

Viscosities of concentrated solution of masticated butylacrylate-acrylonitrile (87/13) copolymers in acetone or toluene were measured by a Brookfield type viscometer.

The effect of rate of shear, concentration $(6 \sim 24 \%)$, molecular weight $\left(2.5 \times 10^{6}-0.47 \times 10^{6}\right)$, temperatture $\left(30 \sim 70^{\circ} \mathrm{C}\right)$ and stability of solution upon the viscosity were studied and the results are summerized as follows.

1. The influence of rate of shear $(D)$

$$
D=\frac{1}{\eta_{A}} \cdot S^{n}
$$

$S:$ shear stress $\propto$ scale of viscometer

$D: \propto$ rpm of viscometer

$\eta_{A}:$ apparent viscosity

$n$ : constant for non newtonian flow

2. The influence of concentration $(C)$

$$
\begin{gathered}
\eta^{\prime} \propto \exp . K_{\mathrm{c}} \cdot C \\
K=2.35 \times 10 \cdot M_{v}+0.15
\end{gathered}
$$

$\eta^{\prime}$ : apparent viscosity at $1 \mathrm{rpm}$

3. The influence of molecular weight $\left(M_{v}\right)$

$$
\eta^{\prime} \propto M_{v}^{3.4}
$$

4. The influence of temperature $(T)$

$$
\eta^{\prime} \propto \exp 1 / T
$$

The apparent activation energy of flow is $2.8 \sim 3.1 \mathrm{Kcal} / \mathrm{mol}$ in $10 \%$ toluene solution at $1.08 \times 10^{6}-$ $0.47 \times 10^{6}$ of molecular weight. 